\title{
Gall stone disease in African patients with sickle cell anaemia: a preliminary report from Yaounde, Cameroon
}

\author{
R F Billa, M S Biwole, A G Juimo, B I Bejanga, K Blackett
}

\begin{abstract}
Cholecystosonography was undertaken in $\mathbf{9 0}$ patients with sickle cell disease aged 15 years and over. Gall stones were found in $26(28.9 \%)$ patients. There was no sex difference, but the incidence increased with age from $13 \cdot 2 \%$ at under 20 years to $75 \%$ at 30 years and over. The mean serum cholesterol and total and unconjugated bilirubin concentrations were not significantly different between patients with and without gall stones. As most $(\mathbf{8 0} \cdot 8 \%)$ stones were radiolucent they were probably of pigment type, containing little or no calcium, and further investigation into how they are produced is needed. Sickle cell patients with acute abdominal crisis should have gall bladder disease excluded before a diagnosis of vascular crisis is made.
\end{abstract}

Sickle cell disease is a major health problem in Africa, especially south of the Sahara. In Cameroon, which stretches from latitude $2^{\circ}$ to $13^{\circ} \mathrm{N}$ of the equator, the carrier state ranges from $10-25 \%$ of the population in the southern parts of the country to $30-40 \%$ in the northern parts. ${ }^{12}$

Anaemia is the commonest complication due to haemolysis of the sickled cells, but the deposition of the resulting excess pigment as a possible predisposing factor to other complications has received little attention.

Sickle cell disease was formerly primarily a paediatric problem, but better management has led to more children surviving to adulthood and thus developing other complications of their disease.

In view of the increase in the number of patients with sickle cell disease who survive into adulthood in our region and also the increased incidence of gall stones with age, ${ }^{3}$ we thought that a study of gall stone disease in this highly selected group of patients was indicated. The hiatus in our knowledge of gall stone disease in Cameroonian patients with sickle cell disease, the need to establish its prevalence, and the need to evaluate radiology as a diagnostic tool led us to undertake this study.

TABLE I Distribution by age and sex of the 90 patients

\begin{tabular}{|c|c|c|c|c|c|c|c|c|c|c|}
\hline & \multicolumn{10}{|c|}{ Age group (years) and sex } \\
\hline & $15-20$ & $20-25$ & $25-30$ & \multicolumn{2}{|c|}{$30-35$} & \multicolumn{2}{|c|}{$35-40$} & \multicolumn{2}{|c|}{$40-45$} & \multirow[b]{2}{*}{ Mean $(S D)$ age } \\
\hline & $F M$ & $F M$ & $F \quad M$ & $F$ & $M$ & $F$ & $M$ & $F$ & $M$ & \\
\hline $\begin{array}{l}\text { Patients with gall stones } \\
\text { Patients with no gall stones } \\
\text { Total No of patients }\end{array}$ & $\begin{array}{rr}2 & 3 \\
22 & 11 \\
24 & 14\end{array}$ & $\begin{array}{rr}5 & 5 \\
14 & 3 \\
19 & 8\end{array}$ & $\begin{array}{rl}7 & 1 \\
6 & 7 \\
13 & 8\end{array}$ & $\begin{array}{l}0 \\
1 \\
1\end{array}$ & $\begin{array}{l}1 \\
0 \\
1\end{array}$ & $\begin{array}{l}1 \\
0 \\
1\end{array}$ & $\begin{array}{l}0 \\
0 \\
0\end{array}$ & $\begin{array}{l}1 \\
0 \\
1\end{array}$ & $\begin{array}{l}\mathbf{0} \\
\mathbf{0} \\
\mathbf{0}\end{array}$ & $\begin{array}{l}24 \cdot 8(6 \cdot 04) \\
21 \cdot 1(4 \cdot 2) \\
22 \cdot 2(5 \cdot 07)\end{array}$ \\
\hline
\end{tabular}

Methods

One hundred consecutive patients aged 15 years and over who were attending the Sickle Cell Anaemia Clinic at the Central Hospital Yaoundé were invited to participate in the study. Exclusion criteria were a haemolytic crisis during the preceding month or a blood transfusion during the previous three months. Ninety patients agreed to participate and were entered into the study, which was carried out from March 1988 to August 1988 inclusive.

A fasting venous blood sample was obtained from each patient, and the haemoglobin genotype (SS) was confirmed by electrophoresis. Cholesterol concentrations were determined using the oxidase method, total bilirubin concentrations using the diazo reaction with diazotised sulphanilic acid in the presence of dimethylsulphoxide, and unconjugated bilirubin concentrations by the diazo reaction without dimethylsulphoxide.

After an overnight fast all 90 patients were screened for gall stones using real time cholecystosonography and a $3.5 \mathrm{MHz}$ transducer. The examination was conducted in both the supine and the left lateral decubitus positions. When the need arose it was carried out in an erect position. Multiple tomographic sections, parallel to and perpendicular to the long axis of the gall bladder were obtained. Gall stones were identified as the presence of intravesicular hyperechogenic structures with acoustic shadows, mobile with gravity in a pear shaped gall bladder whose expanded lower end, tapered proximal contour, and relation to the liver fossa could be seen..$^{45}$

Patients who were found to have gall stones were further investigated by two anteroposterior plain $x$ ray examinations of the abdomen: one centred on the right hypochondrium and the other oblique to the upper quadrant of the abdomen.

Statistical analysis was undertaken using Student's $t$ test.

\section{Results}

Of the 90 patients studied, gall stones were detected in 26 ( 10 male, 16 female), an overall incidence of $28.9 \%$. The gall bladder was not visualised in three cases. Table I gives the age group and sex of the 90 patients.

The mean (SD) age of the gall stone patients was $24.8(6.04)$ years. This was significantly higher than for those without gall stones $(21 \cdot 1$ $(4 \cdot 2)$ years; $p<0 \cdot 05)$. There was no significant difference between the male and female patients $\left(\chi^{2}=0.2613, \mathrm{p}>0.05\right)$

Table II shows that only $19 \cdot 2 \%$ of the stones 
TABLE II $x$ Ray findings of gall stones

\begin{tabular}{lc}
\hline $\begin{array}{l}\text { Type of stone } \\
\text { on } \mathrm{x} \text { ray }\end{array}$ & $\begin{array}{l}\text { No }(\%) \\
\text { of patients }\end{array}$ \\
\hline Radiolucent & $21(80 \cdot 8)$ \\
Radio-opaque & $5(19 \cdot 2)$ \\
Total & $26(100 \cdot 0)$ \\
\hline
\end{tabular}

were radio-opaque. The three patients whose gall bladders could not be seen on ultrasound were lost to follow up.

The mean concentrations of serum total bilirubin $(54.4 \mu \mathrm{mol} / \mathrm{l}, 58.1 \mu \mathrm{mol} / \mathrm{l}$, normal $<17 \mu \mathrm{mol} / \mathrm{l})$, unconjugated bilirubin (37.6, $37.6 \mu \mathrm{mol} / 1$, normal $<12.8 \mu \mathrm{mol} / \mathrm{l}$ ), and cholesterol $(2.8 \mathrm{mmol} / \mathrm{l}, 3.1 \mathrm{mmol} / \mathrm{l})$ were similar for patients with and without gall stones.

\section{Discussion}

The mean age of the sickle cell patients with and without gall stones was $24 \cdot 8$ and $21 \cdot 1$ years respectively. In a parallel study undertaken at the same time, ${ }^{6} 54$ patients (mean age 50 years) of a total of $2195(2 \cdot 5 \%)$ who underwent abdominal echography for various reasons were found to have gall stones. This group of patients is not representative of the general population as it consisted mainly of patients referred by the gastroenterology department because of abdominal pain. This suggests that the true incidence of gall bladder disease in the population is less than $2 \cdot 5 \%$, significantly lower than the $28.9 \%$ found in our group of sickle cell patients, and the mean age was significantly higher. The incidence of gall stones in the patients with sickle cell disease increased with age from five of $38(13 \cdot 2 \%)$ at under age 20 to eight of $21(38 \cdot 1 \%)$ at $25-29$ years. This is in keeping with earlier reports, ${ }^{37}$ and confirms that the risk of gall stones developing in sickle cell patients is age dependent. Unlike non-sickle cell patients the risk did not seem to be greater in women. In our study there was no significant difference in the concentrations of total bilirubin, unconjugated bilirubin, and cholesterol among those who had stones and those who were free of stones. This is in contrast to the results of Sarnaik et al. ${ }^{7}$ The criteria for exclusion in their study, however, was not as rigorous as in our study and a sickle crisis or blood transfusion before sampling may explain their findings.

It seems probable that pigment stone formation in sickle cell patients is related to the increased catabolism of haemoglobin and thus patients with a severe form of the disease would be at an increased risk of gall stone formation. Many patients with severe disease, however, do not survive into adulthood, and by limiting this study to those aged over 15 years we have selected less severely affected patients. In addition, the concentrations of conjugated and unconjugated bilirubin in the serum may not reflect the concentrations of these substances in the gall bladder and as such cannot be used as an indicator of the production of pigmented gall stones.

Patients with haemolytic anaemia, as in sickle cell disease, are likely to have excessive liver secretion of unconjugated bilirubin into the bile in the biliary tract. Bilirubin may be present in substantial amounts, leading to bilirubin 'saturation' and consequent precipitation. Several complex factors that decrease the solubility of unconjugated bilirubin have been proposed in favour of its precipitation. ${ }^{8}$ But the extent of the possible effect of these mechanisms is still controversial.
Only about $10 \%$ of gall stones in the general population are shown by plain $x$ ray of the abdomen. ${ }^{9}$ Radio-opaqueness indicates the presence of over $4 \%$ calcium by dry weight. ${ }^{8}$ Gall stones from patients with sickle cell disease are of the pigment type ${ }^{8}$ and are either bilirubin or calcium bilirubinate pigment stones. ${ }^{10}$ It is believed that the first are formed principally by polymerisation of insoluble unconjugated bilirubin. ${ }^{11-13}$ These stones are formed slowly and because they contain little or no calcium bilirubinate they would obviously not be shown on a plain $x$ ray film of the abdomen. Calcium bilirubinate stones, however, are radiologically opaque and are likely to be precipitated faster than pure pigment stones. ${ }^{14}$ In our study patients with radio-opaque stones were in the younger age range (15-18 years), which seems to support the theory for early precipitation of calcium bilirubinate pigment stones in patients with chronic haemolytic anaemia.

The three patients whose gall bladders we failed to visualise were lost to follow up. There was no evidence that they had scleroatrophied gall bladders due perhaps to gall stones.

Until the advent of echography all episodes of acute abdominal pain in sickle cell patients were ascribed to sickle cell haemolytic crisis. Differentiating between sickle cell crisis and acute cholecystitis may be difficult. The following factors may help in making the diagnosis: (a) the pain and tenderness in the sickle cell crisis is usually generalised and non-specific and associated with a raised serum unconjugated bilirubin concentration. (b) In acute cholecystitis, while early in the disease the pain may be diffuse, the classical picture is of pain in the right upper quadrant with positive Murphy's sign, often associated with fever. (c) Biliary colic, due to gall stones, which may last for several hours is of sudden onset, abating as suddenly as it begins, in contrast to intestinal colic, which consists of paroxysms of pain recurring at intervals of 5 to 10 minutes caused by violent peristalsis of the gut. ${ }^{15}$ (d) Patients with acute cholecystitis complain of pain as the transducer passes over the gall bladder area; and both the total and unconjugated bilirubin concentrations may be normal. ${ }^{6}$ In sickle cell patients with acute cholecystitis, however, it is possible that a haemolytic crisis may occur, and the reverse is also true - that is, the increased production of unconjugated bilirubin from a sickle cell crisis may precipitate acute cholecystitis. Differentiation in these cases is obviously difficult.

We have shown that in sickle cell patients gall stone disease increases with increasing age and thus gall stone disease will become more common as the mean age of the sickle cell population increases. Abdominal ultrasound examination is advised for any patient with sickle cell disease who has an abdominal crisis if episodes of acute cholecystitis are not to be missed.

We thank Dr Monny Lobe for recruiting the patients in his sickle cell clinic into this study and Professor N L Kaptue, Dr Zekeng, Dr B Boum, and Dr F J Gonsu for technical assistance in the laboratory analysis. 
1 Kaptue NL, Mbantenkhu FJ, Nsangou JFI. In: Bowman JE, ed. Geographical distribution of human hemoglobins and thalas semia in Cameroon, Middle and East Africa. Vol II. Amsterdam: Elsevier, 1983: 25

2 Edington GM, Lehmann $\mathrm{H}$. Expression of the sickle-cell gene in Africa. BMF 1955; i: 1308-11.

3 Adekunle DA. Experience with cholelithiasis in patients with sickle cell disease in Nigeria. Am 7 Pediatr Hematol Oncol 1985; 7: 261-4

4 Krook PM, Frank HA, Bush WH, Ginger M, MacLean MD Comparison of real-time cholecystosonography and oral cholecystography. Radiology 1980; 135: 145-8.

5 Gonzalez L, MacIntyre WJ. Acoustic shadow formation by gallstones. Radiology 1980; 135: 217-8.

6 Billa FR Gallstone: clinical and biochemical analysis. Billa FR. Gallstone: clinical and biochemical analysis.
Yaounde, Cameroon: CUSS - University of Yaounde, 1988 . (MD thesis.)

7 Sarnaik S, Slovis TL, Corbett DP, Emani A, Whitten CF Incidence of cholelithiasis in sickle cell anemia using the ultrasonic gray-scale technique. 7 Pediatr 1980; 96: 1005-8.

8 Soloway RD, Trotman BW, Ostrow JD. Pigment gallstones. Gastroenterology 1977; 72: 167-82.
9 Grateau C. Traitement de la lithiase biliaire Vie Médicale 1985; 15: 735-50.

10 Ostrow JD. The etiology of pigment gallstones. Hepatology $1984 ; 4: 215-22$

11 Malet PF, Takabaycoshi A, Trotman BW, Soloway RD, Weston NE. Black and pigment gallstones differ in microstructure and in micro-composition. Hepatology 1984; 4 333-6.

12 Ostrow JD, Celic C. Bilirubin chemistry, ionization and solubilization by bile salts. Hepatology $1984 ; 4$ : 385-455

13 Trotman BW, Ostrow JW, Soloway RD. Pigment versus cholesterol cholelithiasis: composition of stone and bile. cholesterol cholelithiasis: composition of stone and

14 Lombardo A. Contribution â l'étude de la composition des biles et de la nature des calculs biliares chez les lithiasiques Africains en Cote d'Ivoire. Abidjan: Université d'Abidjan 1984. (Thèse d'Etudes Speciales des Maladies de l'Appareil Digestif.)

15 Snodgrass PJ, Americo A. Disease of the gallbladder and bile duct. In: Thorn GW, Adams RD, Braunwald E, Isselbacher KJ, Peterdorf RG, eds. Harrison's principles of internal medicine. 8th ed. London: McGraw-Hill and Kogakusha, 1977: 1621-32. 